J. Clin. Chem. Clin. Biochem.

Vol. 24, 1986, pp. 589-595

(C) 1986 Walter de Gruyter \& Co.

Berlin - New York

\title{
Clinical Evaluation of a New Digitoxin Enzyme-Immunoassay
}

\section{By B. Hoffsümmter}

Charitasklinik St. Theresia, Medizinische Klinik, Saarbrücken

\section{A. Hubbuch, F. Jilek, J. Mattersberger}

Boehringer Mannheim GmbH, Mannheim and

G. Schaller

Stadtkrankenhaus Hanau

in collaboration with

R. Driesch

Abteilung für Klinische Chemie und Pathobiochemie der Kliniken der RWTH, Aachen

D. Lamiable

C. H. R. Hopital Maisons Blanches, Laboratoires de Pharmacologie, Toxicologie, Reims Cedex

K. Lund

Ulleval Hospital, Oslo

Chr. Müller

Klinikum Charlottenburg der Freien Universität Berlin and

Chr. Neuwald

Zentrallabọ, Kaiser-Franz-Josef Spital der Stadt Wien

(Received January 31/April 11, 1986)

Summary: A solid-phase enzyme-immunoassay for the determination of the digitoxin concentration in human serum (Ënzymun-Test ${ }^{\circledR}$ Digitoxin) was developed, and subsequently evaluated in seven laboratories. The test is based on the competition principle. Polystyrene tubes coated with anti-digitoxin antibodies (from sheep) were used as the solid phase. In the concentration range $10-40 \mu \mathrm{g} / \mathrm{l}$, the coefficient of variation for the majority of laboratories was between 2 and $7 \%$. The day-to-day precision only slightly differed from the within-run precision. The measuring range was between 4 and $60 \mu \mathrm{g} / \mathrm{l}$. Enzymun-Test ${ }^{\circledR}$ Digitoxin showed good agreement with three known methods for digitoxin determination. No influence on the values was observed in lipaemic, uraemic and icteric samples, dysproteinaemia sera and in the presence of various digoxin derivatives. The new enzyme-immunoassay permits the practical and reliable determination of serum digitoxin and is suited for use in routine analysis. 


\section{Klinische Evaluierung eines neuen Digitoxin-Enzym-Immunoassay}

Zusammenfassung: Zur Bestimmung der Digitoxin-Konzentration im Humanserum wurde ein FestphasenEnzymimmunoassay (Enzymun-Test ${ }^{\circledR}$ Digitoxin) entwickelt und in sieben Laboratorien evaluiert. Der Test beruht auf dem Kompetitionsprinzip. Als Festphase werden mit Anti-Digitoxin-Antikörpern (Schaf) beschichtete Polystyrolröhrchen eingesetzt. Im Konzentrationsbereich von 10 bis $40 \mu \mathrm{g} / \mathrm{l}$ lagen die' Variationskoeffizienten der meisten Labors zwischen 2 und 7\%. Die Präzision von Tag zu Tag unterschied sich nur unwesentlich von der innerhalb einer Serie. Der Meßbereich erstreckte sich von 4 bis $60 \mu \mathrm{g} / 1$. Enzymun-Test ${ }^{\circledR}$ Digitoxin zeigte eine gute Übereinstimmung mit drei bekannten Methoden zur Digitoxin-Bestimmung. In lipämischen, urämischen und ikterischen Proben, Dysproteinämie-Seren sowie bei verschiedenen Digoxin-Derivaten wurde keine Beeinflussung der Werte beobachtet. Dieser neue Enzymimmunoassay gestattet eine sichere und praktikable Bestimmung des Digitoxins im Serum und ist für den Einsatz in der Routine geeignet.

\section{Introduction}

Provided that suitable sampling times and sampling conditions are used, the determination of glycoside concentrations in human serum provides useful information on the actual intake, the distribution and the excretion of Digitalis glycosides. Digitoxin determinations help on the one hand to avoid dangerous long term effects resulting from the comparatively long half-life of digitoxin $(1,2)$, and on the other hand enable an improved assessment of severe intoxications $(3,4)$.

Measurement of serum glycoside concentrations yields only a limited amount of information, however, on the myocardial uptake of the glycoside and the degree of receptor-binding of the glycoside and its active metabolites, which in the final reckoning is responsible for the action of digitalis. The validity of the information obtained from measurements of the glycoside concentration can be further restricted by additional unexpected and possibly rapidly changing pathological conditions, e. g. renal failure, thyroid gland dysfunctions and derangement of the electrolyte and water balance $(3-6)$.

In addition to the already known immunoassays for determining digitoxin in serum (6-9), a new enzymeimmunoassay has recently been presented (10). The investigation of this test (Enzymun-Text ${ }^{\circledR}$ Digitoxin) in 7 laboratories is described here.

\section{Methods and Materials}

Test principle and test procedure for Enzymun-Test ${ }^{\circledR}$ Digitoxin $\left.{ }^{1}\right)$

Enzymun-Test ${ }^{\circledR}$ Digitoxin is an enzyme-immunosassay based on the competition principle. The digitoxin from the serum sample $(20 \mu \mathrm{l})$ and the digitoxin conjugate $(1 \mathrm{ml}$, digitoxin

1) Commercially available:

Enzymun-Test ${ }^{\circledR}$ Digitoxin

Cat. No.: 759333

Company: Boehringer Mannheim GmbH coupled with peroxidase from horse-radish) compete for digitoxin antibodies attached to the inner wall of polystyrene tubes. After a 30 min period of incubation at room temperature, the non-bound digitoxin conjugate is removed by aspirating the liquid followed by a washing step. A solution of diammonium 2,2'-azino-bis-(3-ethyl-benzothioazoline-6-sulphonate)

$\left(\right.$ ABTS $\left.^{\circledR}\right)$ is then added, and after 30 min the coloration resulting from the wall-bound peroxidase activity is measured spectrometrically at $405 \mathrm{~nm}$. The intensity of colour produced is inversely proportional to the digitoxin concentration. Evaluation is carried out via a hyperbolic calibration curve prepared with the aid of 5 standards. The composition of the reagents is listed in table 1.

Tab. 1. Composition of the reagents used in Enzymun-Test ${ }^{\circledR}$ Digitoxin (manufacturer's information).

1. Binding reaction

Buffer

Phosphate buffer, $\mathrm{pH}=6.8 \quad 40 \mathrm{mmol} / \mathrm{l}$

Bovine serum albumin $\quad 2.5 \mathrm{~g} / \mathrm{l}$

Coated tubes

Wall-bound polyclonal digitoxin antibodies from sheep serum, specificity: see table 4

Digitoxin-peroxidase conjugate

Peroxidase

approx. $30 \mathrm{U} / 1$

Bovine serum albumin

2. Indicator reaction

Phosphate/citrate buffer, $\mathrm{pH}=4.4$

$\mathrm{H}_{2} \mathrm{O}_{2}$ (sodium perborate)

ABTS $^{\circledR}$

$100 \mathrm{mmol} / \mathrm{l}$

$3.2 \mathrm{mmol} / \mathrm{l}$

$1.9 \mathrm{mmol} / \mathrm{l}$

3. Standards

Digitoxin added to digitoxin-free human serum, lyophilised; concentrations:

$0 \mu \mathrm{g} / \mathrm{l}, 7.5 \mu \mathrm{g} / 1,15 \mu \mathrm{g} / 1,30 \mu \mathrm{g} / \mathrm{l}, 60 \mu \mathrm{g} / 1$

4. Control serum

Digitoxin added to digitoxin-free human serum, lyophilised

Sample material and quality control

Human sera from normal donors and patients receiving digitoxin therapy were used for the investigations; fresh sera were used for investigating within-series precision, linearity and interference, whereas deep-frozen sera were used for investigating day-to-day precision and carrying out method comparisons. The control serum contained in the Enzymun-Test ${ }^{\circledR}$ Digitoxin pack was also analysed for quality control purposes. In the method comparisons, the control sera recommended by the respective manufacturers were used. 


\section{Participants, reagents and equipment}

The laboratories taking part in the study are designated with the letters A to G. Results from the Boehringer Mannheim laboratories have been given the letter $H$. The order of appearance of the authors' names on the title page of this paper does not correspond to the sequence $A$ to $G$.

Table 2 provides an overview of the comparison methods, equipment and test variants.

Tab. 2. Participants and their methods.

\begin{tabular}{|c|c|c|c|c|}
\hline \multirow[t]{3}{*}{ Laboratory } & \multicolumn{3}{|c|}{$\begin{array}{l}\text { Working instructions for } \\
\text { Enzymun-Test }^{\circledR} \text { Digitoxin }\end{array}$} & \multirow{3}{*}{$\begin{array}{l}\text { Com- } \\
\text { pari- } \\
\text { son } \\
\text { meth- } \\
\text { ods* }\end{array}$} \\
\hline & \multicolumn{2}{|c|}{ manual } & \multirow[t]{2}{*}{ ES 22} & \\
\hline & without & $\begin{array}{l}\text { with stop } \\
\text { reagent }\end{array}$ & & \\
\hline A & & $x$ & $x$ & 1 \\
\hline B & & $x$ & $x$ & 1,3 \\
\hline C & $x$ & & & 1,2 \\
\hline D & & $x$ & $x$ & 2. \\
\hline $\mathbf{E}$ & & & $x$ & 2,3 \\
\hline$F$ & & & $x$ & 3 \\
\hline $\mathbf{G}$ & & & $x$ & 2 \\
\hline $\mathrm{H}$ & $x$ & $x$ & $x$ & 1,2 \\
\hline
\end{tabular}

*1: RIA 1

2: RIA 2

3: Fluorescence polarisation immunoassay

For the method comparisons, two radioimmunoassays and a fluorescence polarisation immunoassay were used:

Coat-A-Count, ${ }^{125}$ I-Digitoxin (Diagnostic Products, Corp., Los Angeles, Cal., USA), GammaCoat ${ }^{\mathrm{TM}}$, ${ }^{125} \mathrm{I}$-Digitoxin (Clinical Assays, Cambridge, Mass., USA) and Abbott TDx-Digitoxin (Abbott Laboratories, North Chicago, Il., USA).

With the exception of one laboratory, all of the participants used Enzymun-Test ${ }^{\circledR}$ Digitoxin in association with the Enzymun $=$ Test $^{0}$ System ES 22 (Boehringer Mannheim GmbH), hereafter referred to as ES 22. By combining a spectrometer (Photometer 4010), computer (Epson HX-20 microcomputer/Interface 4010) and a pipetting/wash station, ES 22 enables the test to be largely mechanised. Curve fitting is achieved by a cubic spline interpolation (15).

For the manual technique, four laboratories tested a reagent, which can be used to stop the development of colour in the indicator reaction of Enzymun-Test ${ }^{\circledR}$ Digitoxin (EnzymunTest ${ }^{\oplus}$.Stop Reagent, Cat. No.: 811 769, Boehr̈inger Mannheim $\mathrm{GmbH}$ ).

This reagent contains catalase $(=150 \mathrm{kU} / \mathrm{l})$ in an acetate buffer (50 mmol/1, pH 5.5) and $5 \mathrm{~g} / \mathrm{l}$ detergent. By adding $0.1 \mathrm{ml}$ of the stop reagent to $1 \mathrm{mil}$ of substrate buffer solution, the oxidation of the chromogen ABTS ${ }^{\circledR}$ is interrupted, while at the same time the coloured ABTS ${ }^{\circledR}$ radical is stabilised.

\section{Evaluation protocol}

1. Within-series (20 duplicate determinations) and between-day (single values from 10 days) precision of Enzymun-Test Digitoxin was measured in the concentration range from $10-40 \mu \mathrm{g} / \mathrm{l}$.
2. In order to ascertain the lower detection limit, the zero standard was measured 30 times manually (without stop reagent) and with the ES 22 . In accordance with the definition by Kaiser (11), the lower detection limit was calculated from the difference in measured signals between the mean and 3 standard deviations. The results obtained by that procedure were checked by measuring specimens having digitoxin concentrations near the lower detection limit ( $n=20$, digitoxin standards: $2 \mu \mathrm{g} / \mathrm{l}$ and $4 \mu \mathrm{g} / \mathrm{l}$ ).

3. Within the scope of a collaborative study, all of the participants determined three "unknown" human serum-based, lyophilized specimens containing different digitoxin concentrations (duplicate measurements on different 10 days).

4. The specificity of the digitoxin antibody was checked with the digitoxin-like compounds listed in table 4. The interference of 43 commonly used drugs was investigated in vitro using twice the toxic concentrations according to $1 . c$. (12). Lipaemic, uraemic and icteric (up to $171 \mu \mathrm{mol} / \mathrm{l}$ bilirubin) sera were included in the method comparison studies with the reagents named above.

In order to check the possibility of interference by haemolysis, human serum containing $14 \mu \mathrm{g} / 1$ digitoxin was spiked stepwise with haetoolysate up to a final concentration of 20 $\mathrm{g} / \mathrm{l} \mathrm{Hb}$.

The influence of various human sera with pathologically altered protein concentrations (see tab. 3) was investigated by a stepwise blending with a human serum having a high digitoxin concentration.

Tab. 3. Characteristics of human sera from four patients with dysproteinaemia. These sera were used to investigate the influence of dysproteinaemia on Enzymun-Test ${ }^{\circledR}$ Digitoxin (Laboratory E).

\begin{tabular}{llrrl}
\hline Patient & $\begin{array}{l}\text { IgA } \\
(\mathrm{g} / \mathrm{l})\end{array}$ & $\begin{array}{l}\text { IgM } \\
(\mathrm{g} / \mathrm{l})\end{array}$ & $\begin{array}{l}\text { IgG } \\
(\mathrm{g} / \mathrm{l})\end{array}$ & $\begin{array}{l}\text { Kappa/ } \\
\text { Lambda }\end{array}$ \\
\hline 1 & 15.30 & 1.23 & 19.70 & - \\
2 & 0.85 & 92.00 & 8.02 & 7.90 \\
3 & 3.19 & 39.20 & 6.02 & 2.40 \\
4 & 0.42 & 0.65 & 35.90 & 0.02 \\
\hline
\end{tabular}

5. Method comparison studies in human sera were made to investigate the degree of agreement between various test versions of Enzymun-Test ${ }^{\circledR}$ Digitoxin (manual procedure with/without stop reagent; ES 22-procedure).

6. The accuracy of Enzymun-Test ${ }^{\circledR}$ Digitoxin was investigated in the following experiments:

- Recovery of digitoxin in a (digitoxin-free) human serum after spiking with definite amounts of the $60 \mu \mathrm{g} / \mathrm{l} \mathrm{digi-}$ toxin standard. Recovery was checked by visual inspection of the graphic presentation obtained by plotting found concentrations as a function of dilution.

- Comparison studies with human sera covering a wide range of concentrations with three other frequently used tests (tab. 2).

Statistical evaluation was performed according to the standardised principle component analysis $(13,14)$. 


\section{Results and Discussion}

\section{Precision}

Depending upon the concentration, the majority of coefficients of variation were between 2 and $7 \%$ with the day-to-day scatter being only slightly higher than within series (figs. 1 and 2). The test system hence shows good precision in the central concentration range from about 10 to $40 \mu \mathrm{g} / \mathrm{l}$.

When the timing cycles are carefully observed, the values measured manually show precision similar to that obtained with the ES 22 . The procedure is simplified by the stop reagent, which removes the need for careful timing of spectrometric measurements.

\section{Analytical range limits}

In the determination of the lower detection limit values between 1 and $2 \mu \mathrm{g} / \mathrm{l}$ were obtained, with values down to $1 \mu \mathrm{g} / \mathrm{l}$ using the ES 22 . Imprecision studies in that concentration range yielded coefficients of variation of $39 \%(2 \mu \mathrm{g} / \mathrm{l})$ and $9 \%(4 \mu \mathrm{g} / \mathrm{l})$. Thus the diagnostically useful measuring range extends from $4 \mu \mathrm{g} / 1$ to $60 \mu \mathrm{g} / 1$ (highest standard) digitoxin.

\section{Collaborative study}

The results of the collaborative, interlaboratory trial (tab. 4) show interlaboratory coefficients of variation of $4.6 \%, 5.6 \%$ and $6.9 \%$ for the three samples used. These data document a good comparability of values from one laboratory to another.

\section{Specificity}

The results shown in table 5 show that the wallbound digitoxin antibodies are highly specific (laboratory $\mathrm{H}$ ): The metabolites of digitoxin showed cross-reactions of 80 to $100 \%$, whereas all of the digoxin derivatives showed cross-reactions of less than $2 \%$. Cross-reactions of $53 \%$ and $41 \%$ respectively were shown by the alpha- and beta-forms of

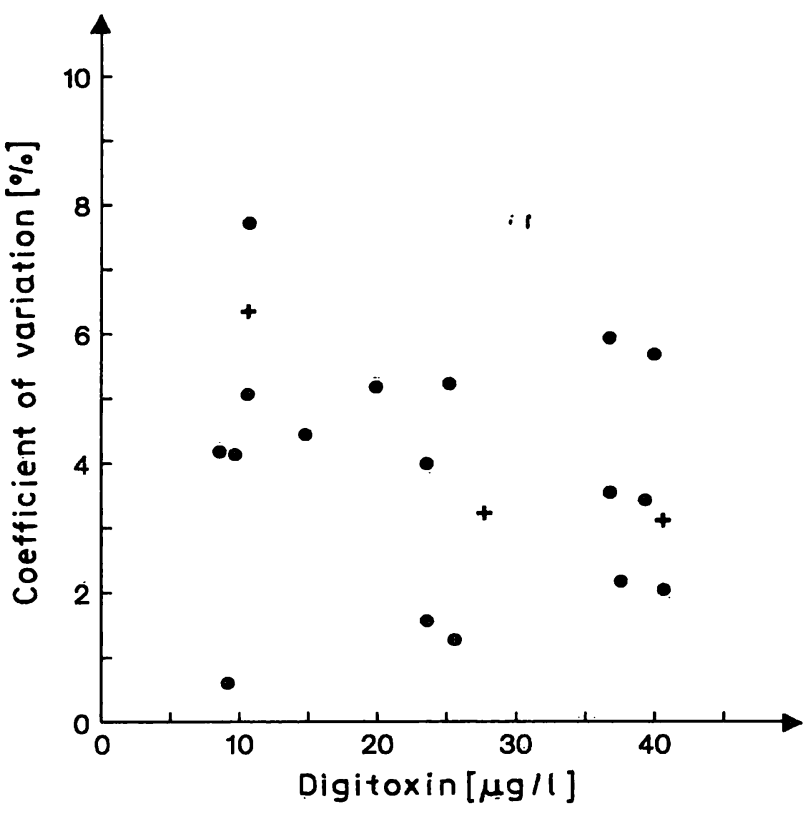

Fig. 1. Within-series precision; groups of 20 duplicate determinations in human sera having differing digitoxin concentrations

+ manual procedure

- ES 22

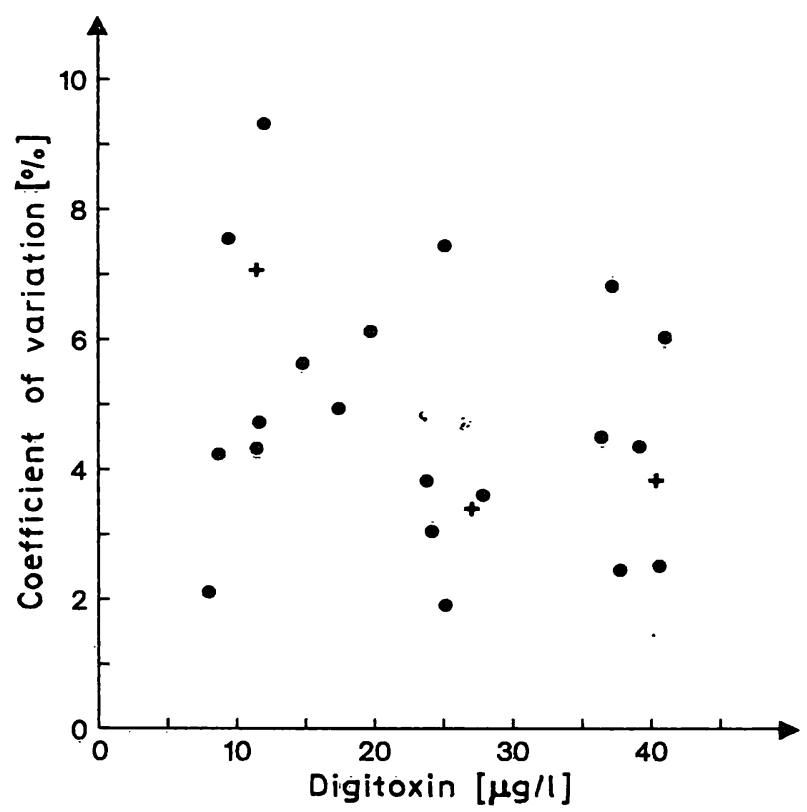

Fig. 2. Day-to-day precision; single values obtained on 10 days from portions of frozen human serum with differing digitoxin concentrations

+ manual procedure

- ES 22

Tab. 4. Results of the collaborative study; duplicate determinations carried out on 10 days (manual in 2 laboratories; with ES 22 in 6 laboratories)

*Lyophilised human serum spiked with digitoxin (approx. 10, 20, $40 \mu \mathrm{g} / \mathrm{l}$ )

\begin{tabular}{|c|c|c|c|c|c|c|}
\hline Sample & $\begin{array}{l}\text { Target value } \\
(\mu \mathrm{g} / \mathrm{l})\end{array}$ & $\begin{array}{l}\text { Mean value } \\
(\mu \mathrm{g} / \mathrm{l})\end{array}$ & $\begin{array}{l}\text { Median } \\
(\mu \mathrm{g} / \mathrm{l})\end{array}$ & Extreme values & & $\begin{array}{l}\text { Inter-laboratory } \\
\text { coefficient of } \\
\text { variation }(\%), \\
(\mathrm{n}=80)\end{array}$ \\
\hline $\begin{array}{l}1^{*} \\
2^{*}(\text { control serum }) \\
3^{*}\end{array}$ & $\begin{array}{l}\overline{20.6} \\
-\end{array}$ & $\begin{array}{l}11.7 \\
20.5 \\
41.0\end{array}$ & $\begin{array}{l}11.7 \\
20.4 \\
40.9\end{array}$ & $\begin{array}{r}9.9=14.6 \\
18.5=23.5 \\
36.7-46.2\end{array}$ & $\therefore$ & $\begin{array}{l}6.9 \\
4.6 \\
5.6\end{array}$ \\
\hline
\end{tabular}


K-strophanthin. Since the simultaneous use of strophanthin (intravenous) and digitoxin is unusual and illogical, this high cross-reaction should not be seen as a disadvantage.

Tab. 5. Cross reactions, calculated on a weight basis (Laboratory $\mathrm{H}$ ).

$\%$ Cross reaction:

$50 \%$ intercept analyte $\times 100$

$50 \%$ intercept cross-reacting substance

\begin{tabular}{|c|c|c|}
\hline Analyte & $\begin{array}{l}\text { Concentration } \\
\text { of the } \\
\text { cross-reacting } \\
\text { substance } \\
(\mu \mathrm{g} / 1) \\
\text { for } 50 \% \\
\text { intercept }\end{array}$ & $\begin{array}{l}\text { Per- } \\
\text { cent } \\
\text { cross } \\
\text { reac- } \\
\text { tion }\end{array}$ \\
\hline Digoxin & 1000 & 1.5 \\
\hline$\beta$-Methyldigoxin & 1150 & 1.3 \\
\hline$\alpha$-Acetyldigoxin & 1100 & 1.3 \\
\hline$\beta$-Acetyldigoxin & 1275 & 1.2 \\
\hline Lanatoside C & 1600 & 1.0 \\
\hline Digoxigenin & 1050 & 1.5 \\
\hline Digoxigenin-mono-digitoxoside & 850 & 1.8 \\
\hline Digoxigenin-bis-digitoxoside & 1050 & 1.5 \\
\hline Digitoxigenin & 90 & 86.8 \\
\hline Digitoxigenin-mono-digitoxoside & 15 & 98.7 \\
\hline Digitoxigenin-bis-digitoxoside & 18.5 & 80.0 \\
\hline Prednisolone & 100000 & 0.02 \\
\hline Spironolactone & 100000 & 0.02 \\
\hline Canrenone & 55000 & 0.03 \\
\hline Prednisone & 100000 & 0.02 \\
\hline Progesterone & 100000 & 0.02 \\
\hline Dihydrodigoxin & 77000 & 0.02 \\
\hline Proscillaridin & 470 & 3.1 \\
\hline k-Strophantin- $\beta$ & 36 & 41.1 \\
\hline k-Strophantin- $\alpha$ & 28 & 52.9 \\
\hline Cortisol & 100000 & 0.02 \\
\hline g-Strophantin (Ouabain) & 2500 & 0.6 \\
\hline
\end{tabular}

\section{Accuracy}

The results obtained in the recovery experiment (fig. 3) show an excellent recovery of digitoxin in serum. As can be seen in table 6, values for the test versions of Enzymun-Test ${ }^{\circledR}$ Digitoxin, carried out on a manual or partially automated basis, are in close agreement.

Results of the same quality were found in comparisons with test kits of other manufacturers (tab. 7).

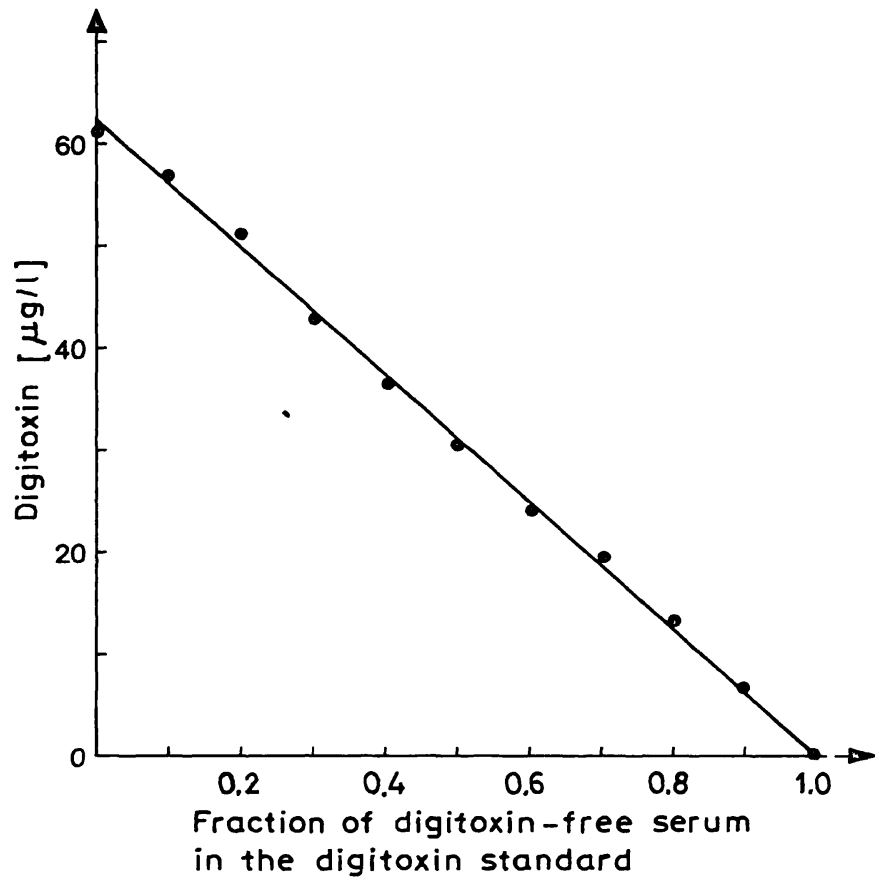

Fig. 3. Recovery of digitoxin in human serum (Laboratory D). The digitoxin standard contained $60 \mu \mathrm{g} / \mathrm{l}$

Tab. 6. Comparison of the three working procedures/applications of Enzymun-Test ${ }^{\circledR}$ Digitoxin

\begin{tabular}{|c|c|c|c|c|c|c|c|}
\hline $\begin{array}{l}\text { Working } \\
\text { specification } \mathrm{x}\end{array}$ & $\begin{array}{l}\text { Working } \\
\text { specification y }\end{array}$ & $\begin{array}{l}\text { Range } \\
\text { tested } \\
(\mu \mathrm{g} / \mathrm{l})\end{array}$ & Regression equation & $\mathbf{r}$ & $\begin{array}{l}\text { Paired } \\
\text { values }\end{array}$ & $\begin{array}{l}\text { Median of } \\
\text { the relative } \\
\text { differences } \\
(\%)\end{array}$ & $\begin{array}{l}\text { Labo- } \\
\text { ratory }\end{array}$ \\
\hline $\begin{array}{l}\text { Manual } \\
\text { Manual }\end{array}$ & $\begin{array}{l}\text { ES } 22 \\
\text { manual/with } \\
\text { stop reagent }\end{array}$ & $\begin{array}{l}5-60 \\
5-60\end{array}$ & $\begin{array}{l}y=-2.108+1.049 x \\
y=0.378+0.921 x\end{array}$ & $\begin{array}{l}0.944 \\
0.908\end{array}$ & $\begin{array}{l}102 \\
102\end{array}$ & $\begin{array}{l}-4.6 \\
-8.6\end{array}$ & $\begin{array}{l}\mathrm{H} \\
\mathrm{H}\end{array}$ \\
\hline $\begin{array}{l}\text { Manual/stop reagent } \\
\text { Manual/stop reagent }\end{array}$ & $\begin{array}{l}\text { ES } 22 \\
\text { ES } 22\end{array}$ & $\begin{array}{l}2-60 \\
8-65\end{array}$ & $\begin{array}{l}y=-1.658+1.075 x \\
y=0.055+0.945 x\end{array}$ & $\begin{array}{l}0.960 \\
0.985\end{array}$ & $\begin{array}{l}70 \\
50\end{array}$ & $\begin{array}{l}-2.9 \\
-5.4\end{array}$ & $\begin{array}{l}\mathrm{A} \\
\mathrm{D}\end{array}$ \\
\hline
\end{tabular}

Tab. 7. Comparison of Enzymun-Test ${ }^{\circledR}$ Digitoxin with other methods

\begin{tabular}{|c|c|c|c|c|c|c|c|}
\hline Test $\mathrm{x}$ & $\begin{array}{l}\text { Test y } \\
\text { Enzymun- } \\
\text { Test } \\
\text { Digitoxin }\end{array}$ & $\begin{array}{l}\text { Range } \\
\text { tested } \\
(\mu \mathrm{g} / \mathrm{l})\end{array}$ & Regression equation & $\mathbf{r}$ & $\begin{array}{l}\text { Paired } \\
\text { values }\end{array}$ & $\begin{array}{l}\text { Median of } \\
\text { relative } \\
\text { differences } \\
(\%)\end{array}$ & $\begin{array}{l}\text { Labo- } \\
\text { ratory }\end{array}$ \\
\hline $\begin{array}{l}\text { RIA } 1 \\
\text { RIA } 1 \\
\text { RIA } 1 \\
\text { RIA } 2 \\
\text { RIA } 2 \\
\text { Fluorescence polarisation } \\
\text { immunoassay }\end{array}$ & $\begin{array}{l}\text { ES } 22 \\
\text { manual } \\
\text { manual } \\
\text { ES } 22 \\
\text { ES } 22 \\
\text { ES } 22\end{array}$ & $\begin{array}{l}7-55 \\
5-40 \\
5-60 \\
4-70 \\
5-65 \\
5-60\end{array}$ & $\begin{array}{l}y=-1.545+1.155 x \\
y=-0.413+1.185 x \\
y=2.078+0.921 x \\
y=3.255+0.908 x \\
y=-0.747+0.991 x \\
y=0.295+1.049 x\end{array}$ & $\begin{array}{l}0.900 \\
0.956 \\
0.911 \\
0.919 \\
0.893 \\
0.976\end{array}$ & $\begin{array}{r}70 \\
45 \\
102 \\
55 \\
102 \\
47\end{array}$ & $\begin{array}{r}7.8 \\
14.1 \\
-\quad 0.1 \\
2.4 \\
-\quad 6.3 \\
3.3\end{array}$ & $\begin{array}{l}\text { A } \\
\mathrm{C} \\
\mathrm{H} \\
\mathrm{E} \\
\mathrm{H} \\
\mathrm{B}\end{array}$ \\
\hline
\end{tabular}




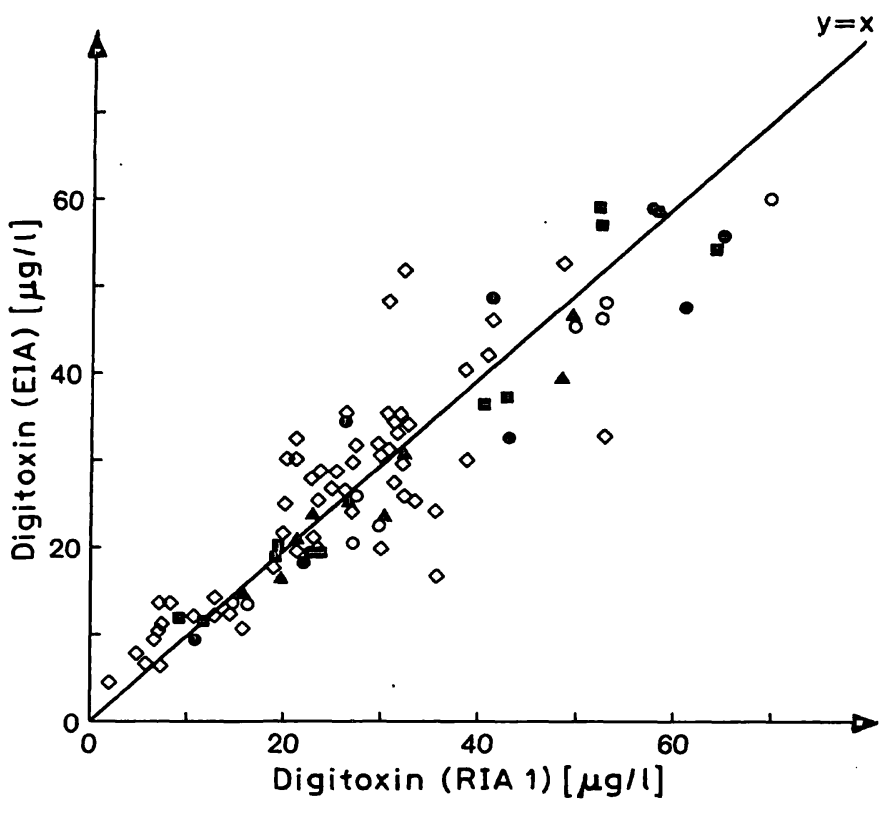

Fig. 4. Comparison of Enzymun-Test ${ }^{\oplus}$ Digitoxin (y) with RIA 1 (x) in 102 human sera (Laboratory $H$, statistical data in table 6)

$\Delta$ : icteric

口: no information

o: lipaemic

o: uraemic

口: dysproteinaemia

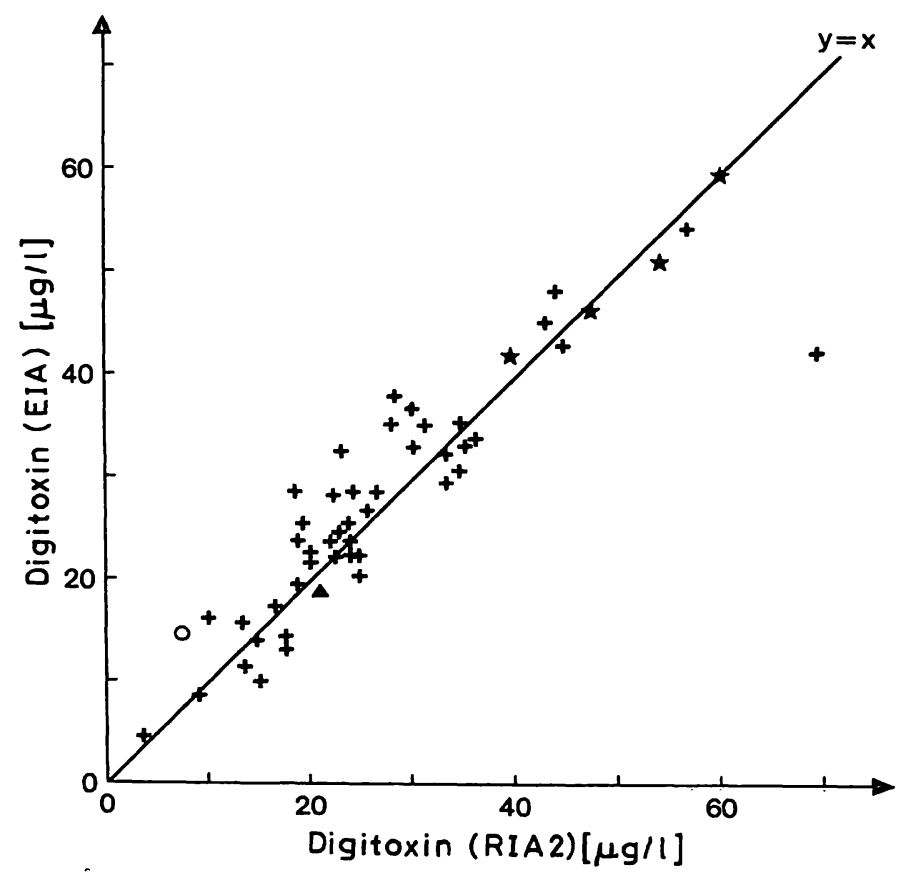

Fig. 5. Comparison of Enzymun-Test ${ }^{\circledR}$ Digitoxin (y) with RIA 2 (x) in 55 human sera (Laboratory E, statistical data in table 6)

$\Delta$ : uraemic samples

$+:$ no information

*: haemolytic samples

$\mathrm{o}$ : containing digoxin
Two typical plots are shown in figures 4 and 5 . As part of the method comparisons, the use of plasma was also investigated (laboratories C, E, F and G). It was found here that irrespective of the anticoagulants used, the values measured for digitoxin were about $10-20 \%$ higher than with serum; for this reason only serum is recommended as sample material.

Since a reference method for the measurement of digitoxin in serum is not available, the accuracy of this new enzyme-immunoassay could only be assessed by recovery experiments and comparison studies with established methods. These investigations indicate that Enzymun-Test ${ }^{\circledR}$ Digitoxin exhibits the same accuracy as accepted radioimmunoassays.

\section{Interfering substances}

No indications of possible interfering factors were found in the method comparison studies in lipaemic, uraemic and icteric (up to $171 \mu \mathrm{mol} / 1$ bilirubin) sera (figs. 4 and 5).

In the drug interference studies all recoveries were between 90 and $110 \%$ in terms of the initial value (tab. 8). The pharmaceuticals shown in table 8 should not therefore lead to any method-mediated influence on the values measured with Enzymun-Test ${ }^{\circledR}$ Digitoxin.

Haemoglobin did not interfere up to the highest concentration tested ( $20 \mathrm{~g} / \mathrm{l}$, 'see fig. 6).

No interferences were observed in the investigations of four human sera containing pathologically altered protein concentrations. The results obtained with the serum from patient 2 (see tab. 3) are shown in figure 7.

\section{Conclusions}

These studies show that Enzymun-Test ${ }^{\circledR}$ Digitoxin produces values for digitoxin that are largely free from interference and which are in good agreement with the results from other commercially available tests. This test is an alternative to radioimmunological methods, and enables the reliable and simple determination of digitoxin, also in smaller routine laboratories.

\section{Acknowledgement}

We would like to thank Mr. McRoberts (Boehringer Mannheim $\mathrm{GmbH}$ ) for translating the original German manuscript into English. 
Tab. 8. Influence of pharmaceuticals, used at twice the toxic concentration (12). Duplicate determinations using the ES 22 (Laboratory H).

\begin{tabular}{lc}
\hline Pharmaceuticals & Recovery \\
& of digitoxin \\
& $(\%)$ \\
\hline Acetylsalicylic acid & 97.3 \\
Ampicillin & 97.1 \\
Meglium salt of amidotrizoic acid & 100.8 \\
Ascorbic acid & 99.7 \\
Meglium salt of iodipamide & 92.7 \\
Glibenclamide & 101.7 \\
Carbochromen & 102.6 \\
Quinidine (bisulphate) & 100.5 \\
Chloramphenicol & 93.0 \\
Chlordiazepoxide & 93.0 \\
Bezafibrate & 99.3 \\
Caffeine & 104.5 \\
Dextran (polyglucose) & 97.9 \\
Etnaverine & 96.5 \\
Furosemide & 91.3 \\
Gelatine & 90.1 \\
Indometacin & 99.9 \\
Methaqualone & 97.6 \\
Methyldopa & 102.4 \\
Nicotinic acid & 102.0 \\
Nitrofurantoin & 96.0 \\
Noramidopyrine-methane-sulphonic acid & 96.8 \\
Oxazepam & 106.5 \\
Oxyphenbutazone & 105.9 \\
Oxytetracycline & 110.0 \\
Paracetamol & 103.7 \\
Phenazopyridine & 104.4 \\
Phenobarbitone & 104.4 \\
Phenprocoumon & 101.1 \\
Phenytoin & 108.1 \\
Probenecid & 106.8 \\
Procaine & 103.6 \\
Pyridamol & 100.3 \\
Pyritinol & 100.6 \\
Sulphamethoxazole & 105.3 \\
Theophylline & 108.1 \\
Trimethoprim & 106.5 \\
Carbimazole & 107.3 \\
Methylthiouracil & 102.8 \\
Allopurinol & \\
Bilirubin & \\
Methotrexate & \\
Dexamethasone & \\
\hline & \\
\hline
\end{tabular}

\section{References}

1. Perrier, D., Mayersohn, M. \& Marcus, F. J. (1977) Clinical Pharmacokinetics 2, 292-311.

2. McFarland, R. T., Marcus, F. I., Fenster, P. E., Graves, '. E. \& Perrier, D. (1984) Eur. J. Clin. Pharmacol. 27, 85-89.

3. Anschütz, F. (1985) Therapiewoche 35, 2562-2568.

4. Kochsiek, K. (1985) Münch. Med. Wochenschr. 127, $950-955$

5. Șmith, T. W. (1975) Amer. J. Med. 58, 470-476.

6. Kramer, P., Schmidt-Lauer, M., Dippoldsmann, H., Rohde, A., Mack, H. P., Friedrich-Fiechtl, J., Gröne, H. J., Sold, G. \& Luig, H. (1981) Ärztl. Forschung 28, 3-35.

7. Böttger, I. \& Pabst, H. W.(1979) Therapiewoche 29, $2589-2602$.

8. Belz, G. G. \& Belz, G. (1979) Med. Klinik 74, 620-623.

9. Ehrenthal, W. \& Prellwitz, W. (1985) Ärztl. Lab. 31, 75-82.

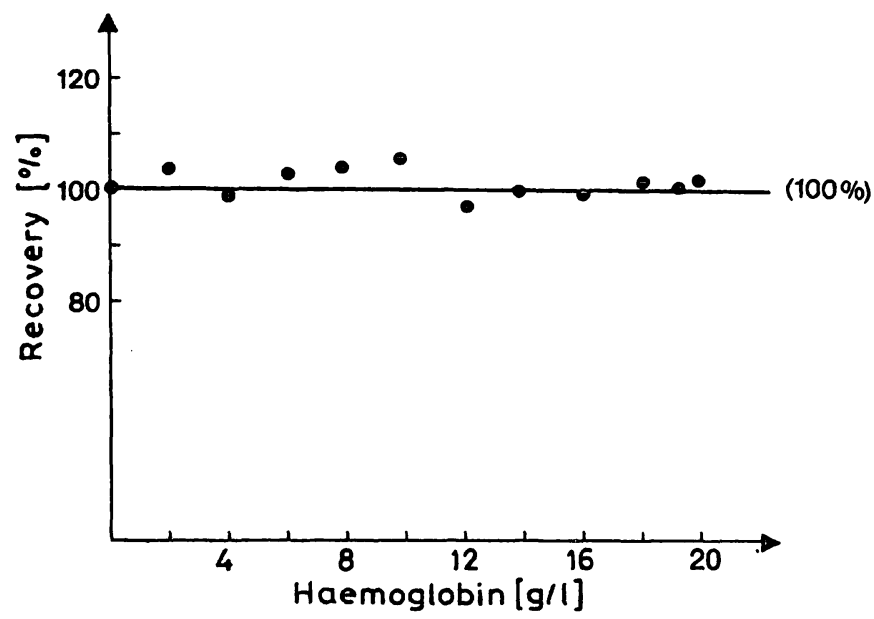

Fig. 6. Influence of haemolysis on Enzymun-Test ${ }^{\circledR}$ Digitoxin carried out using the ES 22 (digitoxin content $14 \mu \mathrm{g} / \mathrm{l}$ )

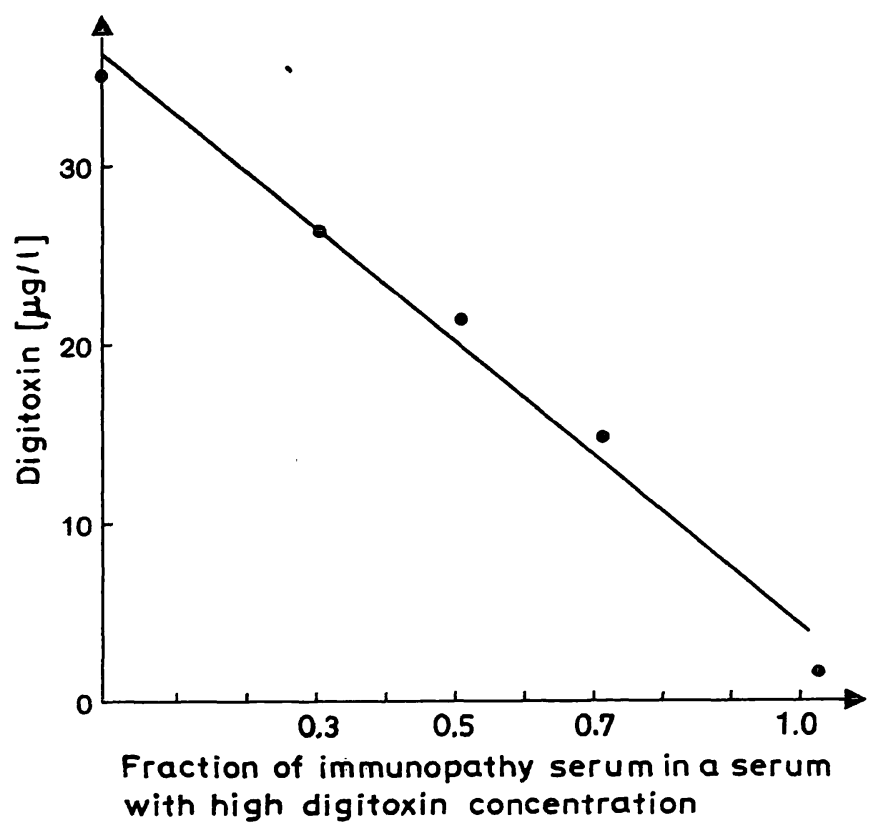

Fig. 7. Influence of a monoclonal immunopathy serum (patient

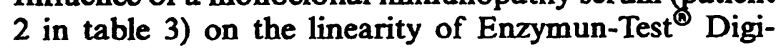
toxin (Laboratory E)

10. Mattersberger, J., Deutsch, G. \& Deeg, R. (1985) Clin. Chem. 31, 905.

11. Kaiser, H. (1965) Z. Analyt. Chemie 209, 1-18.

12. Staber, G., Busch, W. W. \& Koller, P. U. (1982) Med. Lab. $35,10-13$.

13. Haeckel, R. (1980) J. Clin. Chem. Clin. Biochem. 18, 433-437.

14. Eisenwiener, H. G., Bablok, W., Bardorff, W., Bender, R., Markowetz, D., Passing, H., Spaethe, R., Specht, W. \& Völkert, E. (1984) Lab. Med. 8, 232-244.

15. Sandel, P. \& Vogt, W. (1977) GIT Fachz. Lab. 21, 295-298.

Dr. rer. nat. A. Hubbuch

Boehringer Mannheim GmbH

Sandhofer Straße 116

D-6800 Mannheim 31 
